\title{
AJAKIRJANDUS JAKOB HURDA JA MATTHIAS JOHANN EISENI RAHVALUULEKOGUMISE MÕTESTAJANA
}

\author{
KATRE KIKAS
}

\begin{abstract}
Aga mis tuleb hr Eiseni korjamisest meie kõrval arvata? Iseenesest on auustatud suguvennal täis õigus vanavara koguda. Keegi ei ole vanavara põldu enesele päriseks ostnud. Niisamati ei või ka korjajatele keegi ette kirjutada ehk käskida, kuhu nad omad korjandused peavad saatma. Töö ja kaastöö on täiesti vabad. Siiski - asja enese sees on ometi oma kindel siht ja sund, mis meie tähele peame panema, kui tõesti vanavara edasi tahame korjata ja auuga lõpetada. Ma arvan hr Eiseni korjamist enam kahjuliseks kui kasuliseks.
\end{abstract}

(Jakob Hurt, 1893)

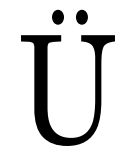

laltoodud kirjalõik pärineb Jakob Hurda 88. rahvaluule kogumise aruande lõpust ning sellisele alustusele järgneb põhjalikum selgitus, miks Matthias Johann Eiseni paralleelne kogumisaktsioon tema arvates kahjulik on. Esile tulevad nii viited Eiseni väljaannete problemaatilisusele kui ka hirm, et kogude paiknemine erinevates kohtades vähendab nende väärtust välis- ja teadusmaailma silmis. Hurt rõhutab, et kogutud materjalidel on teaduslik väärtus vaid siis, kui nad on koos: „Jääme ühtekokku, siis oleme ka siin tugevad ja kaalume teaduse väljal midagi" (Hurt 1893a). Seda, et tema (ja ta korrespondentide) ühisel tööl on teaduslik väärtus, tõendab Hurt viitega rahvusvahelisele teadusmaailmale: „Meie ühine töö on nii tähtsaks ja Eesti nimele nii auusaks arvatud, et temast Venekeeli, Saksakeeli, Soomekeeli, Prantsuskeeli, Ingliskeeli ja Ungrukeeli seletust on tehtud. Teaduse tähtsus, mis meie tööl on, nõuab, et meie materjali väsimata edasi korjame” (Hurt 1893a).

Aruanne ilmub korraga kahes ajalehes - Postimehes ja Olevikus - ning toimetajad tõstavad Hurda sõnumit esile omapoolsete toetussõnadega (Toimetuse poolt 1893; Eesti vanavara 1893), ent erinevalt Hurdast, kes vältis otseseid rünnakuid ning pigem üritas veenda oma korrespondente ühte hoidmise vajalikkuses, pöörduvad nende ajalehtede toimetajad otseselt Eiseni poole ning esitavad nii Hurda nõudmisi mõnevõrra tugevamas sõnastuses: „Sellepärast oleks meie südamesooviks, et auuline vend Eisen oma hakatud töö jälle täitsa vanema venna juhatusele jätaks ja ainult ehk aitajaks heidaks, mitte aga võistlema ei hakkaks” (Eesti vanavara 1893). Ja: „Meie lisame omalt poolt suguvenna Eisenile selle palve tähtsa asja nimel juurde: Lõpetage oma vanavara k o r j a n d u s!" (Toimetuse poolt 1893). Virmaline ja Valgus asuvad aga Eiseni poolele, rõhutavad tema väljaannete olulisust ning süüdistavad Hurta monopoliseerimiskatsetes (Reinvald 1893a; 1893b; Kõrv 1893). 
Hurda 88. aruannet ümbritsev arutelu on vaieldamatult kõige nähtavam osa Hurda ja Eiseni paralleelse tegevuse kaasaegses avalikus kajastuses. Siiski ei kerki see esile päris tühjalt kohalt - hajusamaid ja kohese vastukajata jäänud viiteid on nii varasemast kui ka hilisemast ajast. Samalaadse märkuse oli Hurt paigutanud juba kaks aastat varasema 74. aruande lõppu, siis küll Eisenit otsesõnu ei mainitud, vaid soovitati, et ,auus vanavara aidamees № 2" endale mõne teise tegevusala leiaks (Hurt 1891). Aasta hiljem üritas Hurt Eisenit veenda ka kirja teel (EKLA, f 25, m $5: 18,1$ 3/5-3/6), viimane vastas aga, et tema sooviks on eelkõige Hurta aidata: „Minu meelest on kasulikum, mida rohkem käsi tööd teevad" (EKLA, f 43, m 2 : 49, 1 4/9-4/10, kirjavahetuse kohta vt ka Tedre 1994: 491).

1892. aastal ilmus vähemalt kaks Eiseni tegevust vastustavat kirjutist ka Olevikus (Vanavara korjajalt 1892; Kirjandus 1892), neist esimest refereeris ka Sakala (Tõistest ajalehtedest 1892). 1893. aasta mais Postimehes ilmunud Eiseni „Vanapagana juttude” arvustuses üritas Eduard Vilde aga varasemaid vastanduvaid kirjutisi tasakaalustada, rõhutades, et erinevalt Hurdast, kes „oma korjandusi suureks rahvaluuleliseks teadusetööks saab tarvitama”, on „Eisenil oma vanavara-korjanduste jaoks hoopis teine otstarbe [---]: muisteluulet lõbuks ja õppuseks odavate vihukeste kujul meie rahva laiade hulkade kätte toimetada ja vana kulda ka seeläbi kadumise eest kaitsta" (Vilde 1893a).

88. aruandele järgneb samal aastal Postimehe, Oleviku ja Eesti Postimehe veergudel toimuv Hurda ja Eiseni terminoloogiateemaline arutelu: Eisen teeb ettepaneku asendada vanavara rahvaluulega (Eisen 1893), Hurt kaitseb vanavara kui juurdunud terminit (Hurt 1893b). 1894. aasta veebruaris palub Olevik viitega 1896. aasta muinasteaduste kongressile Eiseni korrespondentidel oma kogutu ka Hurdale saata (Grenzstein 1894a), seda kirjutist refereerib-tsiteerib ka Sakala: Ajalehtede keskel 1894). 1895. aasta „Kasulises Talurahva Kalendris” märgib kirjutise „Rahvaluule ehk vanavara korjamine” autor, et „kui sa soovid, et su korjandus kauemaks ajaks seisma jäeb, saada ta Dr. Hurti kätte". Kui aga oled huvitatud kiirest trükkimisest, „siis kanna selle eest hoolt, et su korjandus Eiseni kätte jõuab" (Rahvaluule 1894: 44). Viimasele reageerib üsnagi teravalt Olevik, ${ }^{1}$ kes avaldab 1894 . aasta detsembris kolmeosalise juhtkirja, kus rõhutab vajadust saata pärimust vaid Hurdale ning taunib igasugust rahvaluule publitseerimist (Grenzstein 1894c; 1894d; 1894e). Järgmise aasta jaanuaris ilmub Olevikus ka kaks toimetaja sissejuhatusega varustatud lugejakirja, mis samuti manitsevad Eisenit kogumistööst loobuma (Grenzstein 1895).

Üheks võimaluseks ülalesitatud diskussiooni tõlgendada on selle asetamine folkloristika kui distsipliini tekkeloo taustale. Viimast on teinud näiteks Eduard Laugaste, kes on näitena Hurda aruannetest hõlmanud raamatusse „Eesti rahvaluuleteaduse ajalugu. Valitud tekste ja pilte” justnimelt 74. aru-

\footnotetext{
${ }^{1}$ Grenzstein põhjendab oma kirjutise vajalikkust viitega kahele erinevale tekstile, millest ühte nimetab ta „pisikeseks kalendriks” ja teist „Tallinna leheks”: „Nüüd tuleb veel midagi juurde, mis meie vaikimise võimataks teeb ja meile rääkimiseks õiguse annab. Üks pisike kalender kirjutab vanavara korjamisest eksitaval viisil ja üks Tallinna leht avaldab ka möödaminnes mõtteid, mis selgust ei too" (Grenzstein 1894c). „Pisikest kalendrit” on tänu tsitaatidele lihtne identifitseerida „Talurahva Kasulise Kalendrina”, kuid viidatud „Tallinna lehte" pole mul õnnestunud määratleda.
} 
ande (Laugaste 1963: 212-213). Ning Ülo Tedre, kes oma artikli „M. J. Eiseni tee folkloristikasse” teises osas „Eisen Hurda võistlejana” (Tedre 1994) suhestab ajakirjanduses toimunut nii Hurda ja Eiseni omavahelise kirjavahetusega kui ka Eiseni suhetega Soome folkloristidega. Laugaste ja Tedre vaade juhtunule on pigem Hurta toetav: nad kasutavad juhtumit kinnistamaks stereotüüpi teaduslikust ja süstemaatilisest Hurdast ning pealiskaudsest ja mitteteaduslikust Eisenist. Eriti selgelt tuleb see esile Tedre käsitluses: ta tsiteerib põhjalikult Hurta toetanud ajakirjanike kirjutisi, kuid Eiseni toetajate kohta on vaid napp joonealune viide Valgusele.

Nii Laugaste kui ka Tedre lähenemine distsipliiniloomele on piiritlev. Viitan siinkohal võttele, mida Charles Briggs on (toetudes teadusloolasele Thomas Gierynile) tähistanud mõistega boundary work ('piiritlemine'): „piiritlemine on retooriline stiil, mis konstrueerib sotsiaalseid piire ning eritleb teadusprestiižiga intellektuaalseid tegevusi mitte- või pseudoteadusest” (Briggs 2008: 93). Folkloristika puhul tähendab see folkloorikandjate (rahvas) ja uurijate-mõtestajate (rahvaluuleteadlased) vahelist eristust. Ehkki piiritlus konstrueeritakse näiliselt loomulikul viisil, loob see olukorra, kus suur hulk folklooriga suhestumise võimalusi ei kuulu justkui kummalegi poole: amatöörfolkloristika, koduloo uurimine, populariseerimine, new age'i liikumises osalemine, ajakirjandus jms. Viimaseid koheldakse kui potentsiaalset ohtu teadlase autoriteedile (üht natuke hilisemast ajast pärinevat, kuid Hurda ja Eiseni vastuoluga võrreldavat juhtumit vt ka Kalkun 2011).

Briggs märgib, et sellise erinevuste ja hierarhiate loomise asemel võiks folkloristika hoopis keskenduda „avarama teoreetikute kogukonna loomisele”, mis hõlmaks lisaks akadeemilistele folkloristidele ka kõiki muid, kes mingilgi kombel folkloori mõtestavad (Briggs 2008: 102). Eesmärgiks võiks pidada jälgimist, kuidas erinevad kogukonnad teadmisi loovad ning kuidas „diskursused ja praktikad nende vahel liiguvad" (Briggs 2008: 102).

Nii ongi üheks põhjuseks, miks olen pidanud vajalikuks seda diskussiooni (taas)vaadelda, see, et juhtum ise oli tunduvalt mitmehäälsem ja vastuolulisem, kui sellest alguse saanud stereotüüp arvata laseks: lisaks Hurdale ja Eisenile võtsid sel teemal sõna ka erinevate ajakirjandusväljaannete toimetajad ning Hurda ja Eiseni korrespondendid. Kõigi nende tõlgendustega peaks täielikuma (ja mitmehäälsema) pildi koostamisel arvestama. Hurta ja Eisenit vastandavat stereotüüpi on varasemalt juba käsitlenud Kristin Kuutma (2005: 93-95) ning kogujate vaatepunkte olen ise puudutanud ühes ettekandes. ${ }^{2}$ Siinses artiklis olen võtnud eesmärgiks just ajakirjanike vaatepunktide esile toomise: küsin, mis neid sellesse arutelusse tõmbas ning milliseid aktuaalseid (nii ajakirjandusesiseseid kui ka üldkultuurilisi) probleeme nad selle abil arutada võtsid.

${ }^{2}$ Rahvaluulekogujate käsitlusi puudutasin põgusalt 2011. aastal konverentsil „Noorte hääled” peetud ettekandes „Jakob Hurda ja Matthias Johann Eiseni vastuolu kajastumine rahvaluulekogujate kirjades". Antud artikli raames on oluline eelkõige see, et peaaegu kõik vastavateemalised kirjutised Hurda ja Eiseni rahvaluulekogudes ühtivad ajaliselt teema ajakirjanduslike käsitlustega, st tundub, et on väga vähe kogujaid, kes tunnetasid spontaanselt Eiseni ja Hurda tegevuse vahelist konflikti, pigem võetakse seisukoht ajakirjandusest loetu mõjul. 


\section{Rahvaluule kogumine ja ajakirjandus: üldist}

Ajakirjandusväljaannete roll rahvaluule kogumise aktsioonide õnnestumises oli väga suur: ilma nende abita oleks nii Hurdal kui ka Eisenil olnud üsnagi keerukas jõuda nii laia auditooriumini ning hoida sellega järjepidevat kontakti (seda aspekti on näiteks rõhutanud Viidalepp 1980 ja Põldmäe 1989). Lisaks sobiva edastuskanali pakkumisele osalesid ajalehed aga ka rahvaluule kaasaegse tähenduslikkuse loomises. Viimast on esile toonud Ülo Valk, märkides: „Rahvaluule mõistmisele esivanemate pärandina aitas rahva seas kaasa eestikeelne ajakirjandus. Võime täheldada, et folkloori olemasolu ühiskondlik teadvustamine ja massimeedia mõjukuse kasv kulgesid paralleelselt" (Valk 2008: 61$)^{3}$

Ning kuna tegu ei olnud erialaajakirjade, vaid nn tavainimestele suunatud ajalehtedega (kus aktsioon konkureeris lehepinna ja lugeja tähelepanu nimel muude tolle aja jaoks oluliste teemadega), aitasid ajalehed ka siduda kogumisaktsiooni kaasaegse kultuurieluga. Näiteks Ea Jansen on kirjutanud, et Hurda kogumisaktsiooni tähendus ei „piirdu üksnes eesti folkloristika uurimisbaasi rajamisega”, vaid „tegu on oma aja sümboolse sotsiaal-kultuurilise aktsiooniga" (2004a: 19, vt ka nt Peegel 1994: 194). Ka on esile tõstetud, et tegu oli ühe kõige paremini toiminud üldrahvaliku ettevõtmisega venestusajal (Jansen 2004c: 182, vt ka Peegel 1994: 190). Seega: ehkki Hurt rõhutas mitmelgi puhul oma tegevuse teaduslikkust (näiteks olukordades, kus kogumist võrreldi ebausu levitamisega, vt nt Hurt 1888; 1889), siis ajalehtedes oli rahvaluulekogumine üheks rahvuslikuks ühisettevõtmiseks paljude teiste seas.

Benedict Anderson on viidanud ajalehtede rollile rahvusliku ühtekuuluvustunde tekkimises (vrd Anderson 2006: 25-36), kuid Eesti kontekstis ei seisnenud ajalehtede olulisus kindlasti ainult Andersoni esiletoodud ühise lugemiskogemuse tunnetamises, vaid ka selles, et ajalehtede tegemises oli võimalik sõnumite saatmise kaudu ise osaleda. Jansen on märkinud, et sõnumite saatmine ajalehtedele kujunes „üheks eestlaste tüüpiliseks vaimse eneseavaldamise vormiks" (Jansen 2004b: 85). Kuna rahvaluulekogumine tähendas aga reeglina ka kogujate nimelist mainimist ajalehes, võib seda käsitleda kui omamoodi variatsiooni ajakirjandusele kaastööde kirjutamisest (seost tugevdab ka see, et kogutavaid materjale oli Hurdale/Eisenile võimalik edastada ajalehetoimetuste kaudu).

Järgnevalt vaatlen konkreetsemalt kaht teemat, mis Hurda 74. ja 88. aruandes eriliselt esile tõusevad ning mida edasises diskussioonis aktiivselt kommenteeritakse-kritiseeritakse: Hurda nõue, et Eisen endale oma p õ ll u m a a leiaks ning tema suhtumine Eiseni koostatud rahvaluuleväljaannetesse. ${ }^{4}$

${ }^{3}$ Ajakirjanikud on oma rollist kohati vägagi teadlikud. Näiteks kirjutab K. A. Hermann R. G. Kallase raamatu „Saaroni Valge Lill Pulmapäevaks. Perekonna-raamat” (1894) arvustuses: „....aga see on meie arvates kaljukindel tõde, et Dr. Hurt ilma ajalehtedeta mitte midagi ei oleks teha võinud. Ajalehed on need olnud, kes teda kõrgele upitasivad „vanavara kuninga" auujärjele. Tema hüüded, soovid ning aruanded leidsivad üksnes ajalehtede läbi teed rahva sekka ja südamesse, ning rahvas hakkas kaasa töötama, siis läks asi. Üteldagu meile, kus on ajalehtesid selle eest kiidetud või tänatud, et nad selle hiigla-töö on ära teinud?" (Hermann 1895.)

${ }^{4}$ Tegelikult vääriks detailsemat vaatlust ka terminoloogia küsimus. Eisen võttis rahvaluule mõiste kasutusele küll juba 1892. aasta lõpus, kuid selle avaliku kontseptualiseerimi- 


\section{Rahvaluule kogumine ja ajakirjandus: diskussiooni osalised}

Märkimisväärseks osaks tolleaegsest ajakirjandusväljast olid ajalehtede omavahelised vaidlused: teineteise tegemistel ja arutlustel hoiti tähelepanelikult silma peal ning kui vähegi põhjust oli, siis tsiteeriti-refereeriti loetut, kord kaasa kiites, kord täielikult maha tehes, kord argumenteerivamalt, kord isiklikumalt (üht Hurda 88. aruandele järgnenud diskussiooniga samal ajal toimunud arutelu on analüüsinud nt Jansen 2004d, üldisemalt on sama teemat esile tõstnud nt Peegel 1994: 193, Lauk 1994a: 200, Aru 1994: 211-212). Vaadeldavat vaidlust võib tolleaegse ajakirjanduse taustal nimetada pigem vaoshoituks.

Kõigepealt visandan aga nelja aktiivseimalt osalenud ajalehe (nendeks on Olevik, Postimees, Virmaline ja Valgus) rahvaluuleprofiilid ehk siis selle, mil määral ja millisel toonil olid nad end kogumistööga sidunud ning rahvaluule kogumisega seonduvat vahendanud.

Kui üritada neid ajalehti kuidagi omavahel suhestada, jääb kohe silma geograafiline levik, mis huvitaval kombel ühtib ka jaotusega Hurda ja Eiseni toetajate vahel. Oleviku ja Postimehe toimetus asusid Tartus ning ehkki neil oli lugejaid ka Põhja-Eestis (Postimehel oli Tallinnas isegi abitoimetus), levisid nad siiski pigem Lõuna-Eestis. Valgus ilmus Tallinnas ning oli kõige suurema levikuga Põhja-Eesti eestikeelne leht (Lauk 1994a), Virmaline ilmus Rakveres ning talle viidatakse kui pigem kohaliku levikuga lehele (Lauk 1994b). Ka on välja toodud, et kui Valgus ja Virmaline lähtusid eelkõige C. R. Jakobsoni Sakalas valitsenud ideoloogiast (Lauk 1994a; 1994b), siis Olevik oli Eesti Kirjameeste Seltsi Hurta pooldanud liikmete häälekandja (Peegel 1994: 179). On aga raske öelda, kui palju see vastuolu käesoleva diskussiooni osapooli mõjutas. ${ }^{5}$

Jaan Reinvaldi toimetatud Virmaline ei olnud diskussioonile eelnenud ajal avaldanud Hurda aruandeid, küll aga avaldas üsna regulaarselt Eiseni omi. Seega on oodatav, et ajaleht ei asu mitte üksnes Eiseni poolele, vaid üritab võtta ka Eiseni eestkõneleja rolli. Näiteks leiame 1893. aasta 9. septembri lehest märkuse: Eisen ei soovi Virmalise vahendusel Postimehe ja Oleviku süüdistustele vastata, et mitte lõhet suuremaks ajada (Toimetuse tähendus 1893). Virmaline märgib ka, et rahvaluulekogusid ei pea ju ilmtingimata kohe kokku koondama: eeskujuks võiksid olla näiteks arheoloogiliste esemete kogud, kus „vanad rahad, sõjariistad, ehte asjad, surnuluud j.n.e - mitmes ja mitmes muinaskogus seisavad ja iga vanaaja uurija neid seal ehk teal võib

seni jõudis ta alles aasta hiljem (1893). Et see käik võis olla mõjutatud vastuolust Hurdaga, võiks antud diskussioon teadusloos kajastuda ka kui tänapäeval mitme rahvaluulega tegeleva institutsiooni (nt Eesti Rahvaluulearhiiv, TÜ eesti ja võrdleva rahvaluule osakond, Akadeemiline Rahvaluule Selts) nimesse jõudnud rahvaluule mõiste juurutamise algushetk. Tedre viitab rahvaluule mõiste tõlkelaenulisusele (vt Tedre 1994: 490). Siinsest artiklist otsustasin teema siiski välja jätta, kuna teised osalised end terminoloogiliste probleemide arutlusse tõmmata ei lase (valdavalt kasutatakse vanavara, kuid ka näiteks vanakulda jm metafoore). Erandiks on Grenzstein, kes Eiseni ettepanekut siiski põgusalt mainib (Grenzstein 1894c).

${ }^{5}$ Probleemi aktuaalsusest kõneleb Rudolf Põldmäe tähelepanek, et mõned rahvaluulekogujad viitasid Hurda-Jakobsoni vastuolule kui kogumistööd raskendavale asjaolule (vt Põldmäe 1989: 19). 
uurida ja nendest kirjeldada, mis ta hea ja kasuliku tunneb olema" (Reinvald 1893b). Tuleviku uurijad võivad aga alati ka ühendamisele mõelda:

Kui tulevad põlved kõik Kreutzwaldi, Bertrami, Sohbergi, Hurti, Eiseni j.n.e. kogutud ja väljaantud muinasvara üheks koguks kokku ühendavad, teisenditega täiendavad, nende kallal sirgeldavad, hööveldavad, viilivad ja kritikat teevad, siis on nad nende korjajate ja vanavara alali hoidjate vastu ühte viisi tänulikud, sest ilma nendeta ei oleks neil midagi sirgeldada, hööveldada ega viilida (Reinvald 1893b).

Samas pole Virmalise lähenemine kaugeltki nii isetu ja neutraalne, nagu ta ehk näidata soovib: nimelt käsitleb toimetaja Hurda rünnakut Eiseni vastu ka kui rünnakut nende ajalehtede vastu, kellega Hurt koostööd ei tee, ühendades nii justkui vaid rahvaluule kogumisse puutuva probleemi hoopis ajakirjandusmaastiku siseste pingetega. Ta märgib, et kui rahvaluulekogumises on mingi lõhe, siis on selle taga Hurda komme avaldada oma aruandeid vaid valitud ajalehtedes, jättes teiste ajalehtede lugejaskonna emata lapsiks:

Hr. Hurt aga seisab korjanduse algusest saadik lahutuse kuristiku kaldal, kuna tema ainult kahes Eesti ajalehes omad üleshüided ja aruanded on avaldanud ja teised lehed, kelle lugejate arv ühtekokku ammugi nende kahe lehe lugijate arvust üle käib, nii ütelda „emata lapsiks” on jätnud. Kui Hr. Hurt kui osav vanavara korjaja ilma lõheta ja ilma erakonna ajamiseta kasuga üleüldist teaduslist tööd tahtis teha, siis pidi tema ka seda arvata teadma, et need teised Eesti ajalehed mitte kümneid aastaid Jumala tuulest ei ole elanud, vaid et neil ka lugejad on, lehe ülesse piavad ja et need lugejad, kui nad vanavara korjajad tahavad olla, isegi Hr. Hurtist endid sundida ei lase neid lehti tellima ehk sealt tealt otsima, kus vanavara korjajate vastused sees on. Meie ei või midagi selle juure parata, kui mõned inimesed seesugust asja seisukorda nähes seda vanavara korjamist ajalehtede lugejate ja erakonna liikmete püidmise lõksuks nimetasivad (Reinvald 1893a). ${ }^{6}$

K. A. Hermanni toimetatud Postimehe asend on tunduvalt ambivalentsem. Ajaleht on avaldanud nii Eiseni aruandeid kui ka positiivseid ülevaateid tema rahvaluuleväljaannetest (nt Kirjandusest 1893), sh selgitanud paar kuud varem oma lugejatele, et Eiseni ja Hurda eesmärgid on nii erinevad, et nende mõlema töö on eesti rahva jaoks vajalik (Vilde 1893a). Tüli puhkedes ilmub küll toimetusepoolne Hurta toetav kirjutis (Eesti vanavara 1893), kuid Eiseni aruanded ilmuvad Postimehes sellegipoolest edasi ${ }^{7}$ ning ka Eiseni rahvaluuleväljaannete ülevaated on jätkuvalt positiivsed (sh vaid kolm päeva pärast 88 . aruannet ilmunud ülevaade „Rahva-raamatu” teisest osast: vt Vilde 1893b). Postimehe positsiooni muudab eriliseks ka see, et kui teiste ajalehtede puhul võib kirjutisi seostada peatoimetajatega, siis Postimehe poolt osaleb diskus-

\footnotetext{
${ }^{6}$ Sarnase etteheite suunas 1888. aastal Hurdale ka Virulane: „Kui Dr. Hurt oma palumistele üleüldist rohket osavõtmist soovib, mis muidugi nii on, ehk oleks siis see tema tähtsale püidele tuluks, kui ta üleüldisemal viisil selles asjas paluks, mitte vahet pidades ja vahet alles hoides ainult kahe avaliku lehe läbi" (Teistest ajalehtedest 1888).

${ }^{7}$ Väike avaldamispaus tekib küll paar kuud hiljem, kuid selle põhjuseks on hoopis Hermanni nördimus, kui ta avastab, et Eisen (keda Hermann peab oma ajalehe kaastööliseks) on kirjutanud Eesti Postimehele juhtkirja (KM EKLA, f 25, m $5: 4,13 / 3$ ).
} 
sioonis mitu erinevat inimest (päevalehe puhul on selline vastutuse hajumine ehk loomulikki): Eisenit toetavad tekstid on kirjutanud Eduard Vilde, samas kui Hurta toetava kirjutise autoriks on keegi tolleaegsetest toimetuse liikmetest - Hermanni enda osalus on äärmiselt ebatõenäoline, kuna 1893. aasta augustis oli ta tervislikel põhjustel Saksamaal (vt nt Jansen 2004d: 326-327). ${ }^{8}$

Hoolimata kirjutise üsnagi selgelt Eiseni tegevust vastustavast toonist üritab see samas manitseda järgnevaid sõnavõtjaid vaoshoitusele, justkui aimates, et potentsiaalselt võib keskmesse tõusta küsimusi, millel rahvaluule kogumisega tegelikult mingit seost polegi:

Kui kellelgi selle kohta avalikult midagi ütelda peaks olema, leht on seks ikka lahti. Kuid selle eest hoitagu, et asja juurest mitte isiku kallale ei minda. „Sine ira et studio - vihata ja vaenuta!" olgu meil juhtmõtteks - siis on kindel, et kõnelolevast asjast mitte üle küla kuulduv tüli ei tõuse. Sine ira et studio! (Eesti vanavara 1893).

Ka Ado Grenzsteini toimetatud Oleviku lähtepunkt on ambivalentne, kuid diskussiooni tekkides toimub üsnagi ühene positsioneerumine. Olevik on olnud aktiivne Hurda toetaja ja kritiseerinud väljaandeid, kus Hurda üleskutseid-aruandeid ei avaldatud (nt Mis teevad teised lehed? 1888). Olevikus on ilmunud ka vähemalt kaks Eiseni tegevust vastustavat kirjutist (Vanavara korjajalt 1892; Kirjandus 1892). Kuid seal on ilmunud ka positiivseid ülevaateid Eiseni rahvaluuleväljaannetest (nt Kirjandus 1893a) ning mitmeid Eiseni üksikteemadele keskenduvaid kirjutisi-üleskutseid. Grenzsteini positsiooni iseärasuseks on see, et ta näib justkui otsivat võimalust teema aktiivsena hoidmiseks (vt nt Grenzstein 1894a; 1894c; 1894d; 1894e). Seda erilisust rõhutab Grenzstein ka täiesti eksplitsiitselt: „Nagu meie lugejatel teada, ei võta meie mõnda aega enam tema [Eiseni $-K . K$.] aruandeid ülesse, aga ka see ei aita, sest mõned teised lehed teevad seda häämeelega, isegi ka need, kes Eiseni korjamist hääks ei kiida" (Grenzstein 1894c).

Grenzsteini kirjutise põhisõnumiks on täielik vastuseis rahvaluule kohesele trükkimisele, kuid artiklil on ka konstruktiivsem pool, kus ta esitab plaani, kuidas vanavara valdkonda üldse edasi arendama peaks: $\mathrm{k}$ o g u rahvaluule tuleb kokku korjata ning ühte kohta (ta soovitab Tartut) kokku koguda; materjale tuleb hoida tulekindlas kapis ning neile tuleb koostada kä si kirja lik a sja-juhtkava; neid tuleb võimalikult suures mahus saksa keelde tõlkida ning kui kõik eelnev valmis, saab asuda väljaannete koostamise juurde (Grenzstein 1894e). Samal ajal on põnev see, et samas ajalehenumbris, kus Grenzstein vastustab Eiseni tegevust, ründab ta ka Jaan Jungi, märkides, et viimase kavandatud arheoloogiliste paikadega seotud teadete kogumine dubleerib R. Hausmanni tegevust (vt Grenzstein 1894b) - seega ei piirdu Oleviku korralduslik ambitsioon vaid rahvaluule teemaga, vaid iseloomustabki tema üldist suhestumist kultuuriruumi kui tervikuga.

${ }^{8}$ Ka kirjutisega tutvunud Krista Aru välistas K. A. Hermanni autorsuse nii stilistiliselt kui sisuliselt (Hermann pidas Eisenit oma sõbraks ega oleks tema kohta avalikult nii kirjutanud). Võimalike autoritena tõi Aru esile neli isikut: Peeter Grünfeldt, Oskar Kallas, Jaan Lammas ja Hindrik Prants. Hetkel ei ole mul õnnestunud konkreetsemaid tõendeid leida, kuid näib tõenäoline, et kirjutajaks võiks olla keegi rahvaluule kogumise kogemusega inimene (nimetatutest puudub see aga vaid Jaan Lammasel). 
Osalevatest ajalehtedest kõige keerukam on tabada Jakob Kõrvi toimetatud Valguse lähtepunkti - ajalehte sirvides ei jäänud seal silma ühtegi rahvaluule aruannet või üleskutset (kuigi Kõrv oli seotud Eesti Kirjameeste Seltsi rahvaluule kogumisega). Samas on kõnekas, et erinevalt Virmalisest, kes astus dialoogi nii Postimehe kui ka Olevikuga, suunab Valgus oma repliigi üksiti Oleviku suunas (ning pälvib ka iroonilise vasturepliigi, vt Kirjandus 1893b). Seega võis Valguse sekkumise üheks lähtepunktiks olla just soov Olevikuga vaielda (ning see soov võis olla mõjutatud ka tema poolehoiust Jakobsonile). Kõrvi vastus on huvitav aga selle poolest, et viitab kujundlikult kahe ajalehe erinevale geograafilisele mõjupiirkonnale. Sealjuures teeb ta seda, arendades edasi Hurda 88. aruandes kasutatud metafoori rahvaluulest kui veevoost, mis vabrikut käigus hoiab. Nii kirjutas Hurt, et Eiseni tegevus „lõhub vee teaduse-hallikast kahte harusse ja üksik haru on muidugi noorem kui ühendatud vesi. Vee jõud väheneb, vabriku töö saab kahju" (Hurt 1893a). ${ }^{9}$ Valgus vastab sellele, et see kõlab, nagu Emajõgi ütleks Narva jõele: „Jäe sina seisma, sest mina hakkasin oma jooksu enne mäe poolt alla. [---] Eesti vesi läheb lahku, kui igaüks jõgi omalt poolt edasi jookseb" (Kõrv 1893). Narva jõe vastus viitab ühelt poolt kogu rahvaluule kokku kogumise võimatusele, teisalt aga ka liigse ühtsustamisega kaasnevatele tagasilöökidele:

Oovame ikka peale, oovame mõlemad; - veed maalt ei lõpe; ega rahva vanavara otsa saa. Mis täna uus, jäeb homme juba vanaliiki, [---] Iga jõgi, - ja olgu see ka rahvalikkude vaimu-päranduste-vete-vool, - teeb iseeneselle otsa peale, kui ta ühte kokku kogusse oovab ja teistele jõgedele teed ei luba - ta saab jo sell viisil mädaks sooks.... (Kõrv 1893).

\section{Keele metafoorsus: vanavara põld}

Äsjatsiteeritud Valguse arendus Hurda kasutatud kujundist toob esile ühe vägagi olulise osa diskussioonist: osalejate keelekasutus on võrdlemisi metafoorne ning ehkki viidatakse ka muudele kujunditele, tulevad esiplaanile eelkõige need, mis on rohkem või vähem dialoogis Hurda keelekasutusega. Need metafoorid on omamoodi diskussiooni kooshoidev jõud, ühine keel, milles kõnealust probleemi vaetakse.

Üheks diskussioonis aktiivselt kasutatud metafooriväljaks on põllundusega seotud kujundid. On üsnagi põnev, et ehkki Hurt kasutas rahvaluule kogumise kirjeldamisel paljusid erinevaid metafoore, on just t a l u p oj a va a de (ingl farmer's field of vision, vt Valk 2004) see, mida temaga seoses kõige sagedamini esile tuuakse: ikka viidatakse pidulikel puhkudel Hurdale kui v a n a var a a id a m e he le, kes õhutas kogujaid variseda ähvardavat vilja kokku koguma ja oma salvedesse kandma. Ülo Valk on märkinud, et põllumajandusega seotud metafooride kasutamine andis Hurdale võimaluse siduda üsnagi ebamäärane rahvaluulevaldkond millegi reaalelulisemaga: „Maalähedases Eesti ühiskonnas polnud lihtne selgitada ja väärtustada midagi nii ebamää-

\footnotetext{
${ }^{9}$ Sama metafoor on silma jäänud ka Virmalisele: „Mõnigi vabrikant vaatab vesiste silmadega pealt, kuidas üks osa kasutoojat ja kallist vett naabrivabrikandi rataste peale voolab [---]. Maailma elu ja olu käik on kord seesugune, et üks kõike igatahes oma käpa alla [monopoliserida] ei saa" (Reinvald 1893b).
} 
rast kui suuline pärimus ning lihtsam oli uusi ideid tutvustada edumeelse talupidamise sõnavaraga, mis oli enamikule inimestele arusaadav" (Valk 2004: 267). Samas on aga vaja meeles hoida, et sama metafoorivälja kasutati lisaks rahvaluulekogumise kirjeldamisele muude kultuurivaldkondade toimimise kirjeldamiseks. Nii leiame kaasaegses ajakirjanduses viiteid kirjanduse-, teaduse- või keelepõllule, ning neis valdkondades toimuvat kirjeldatakse kui külvi, lõikust, tuulamist vms (vrd ka Valk 2004: 266). Seega: lisaks abstraktse nähtuse konkretiseerimisele võimaldas põllutööst lähtuv kirjeldus uue nähtuse (s.o rahvaluule kogumise) seostamist tolleaegse kultuuri ja selle kirjeldamiseks kasutatava keelega. See tähendab aga ühtlasi seda, et diskussioonis osalejad tõlgendasid kasutatavaid metafoore mitte üksnes konkreetsetes tekstides esilolevast lähtuvalt, vaid toetudes ka oma varasematele kogemustele selle kujundivälja rakendamisel.

Hurda 74. ja 88. aruandes kerkib esile üks väga konkreetne võimalus põllunduslike metafooride kasutamiseks. Kui tema muudes kirjutistes on esiplaanil metafoori võime rõhutada rahvaluule väärtuslikkust (mida rohkem meil seda salves on, seda rikkamad oleme) ning vajadust kogumistööga kiirustada (rahvaluule on kui variseda ähvardav vili), siis antud kirjutistes loob ta selle abil pildi kultuurist, mis jaguneb selgelt eristuvateks valdkondadeks (põldudeks), millest ideaalis peaks igaühel olema üks konkreetne eestvedaja. Nii märgib ta küll alustuseks, et „Keegi ei ole vanavara põldu enesele päriseks ostnud”, kuid jätkab: „Hr Eiseni kirjamehe and ja väga nobe sulg saaksivad meie rahvale palju enam tulu tooma, kui ta oma osavust teise kirjanduse põllu pääl pruugiks. Kirjanduse väli on väga lai, aga töötegijaid vähe. Hr Eisenil on mitu kirjamehe põldu küllalt tuttavad ja harjunud. Mis sunnib teda otse senna minema, kus juba 30 aastat oma töötegija on?" (Hurt 1893a.) Seega: lisaks sellele, et põllumetafoor oli efektiivne viis õhutada talutaustaga inimesi kogumistööga ühinema, toimis see sama tõhusalt ka teatavate tegutsejate ja tegutsemisviiside ebasobivuse esile toomiseks.

Hurda 88. aruandele vahetult järgnenud kirjutistest on põllu metafoor kõige selgemalt esil Virmalises. Seda võib nimetada isegi üheks kirjutise keskseimaks ja tooniandvaimaks kujundiks: just sellele metafoorile on Reinvald rajanud oma teksti sissejuhatavad lõigud. Samas pole kujundi ülesandeks mitte piiritleda, vaid rõhutada ettevõtmise kiireloomulisust:

Kui vili põllul küps on, siis ruttab põllumees kõiki saadaval olevaid jõudusi ja abinõusi kokku võttes lõikusele, et see õigel ajal ja enne kokku saaks pandud, kui ta pudenema hakkab, enne kui tuuled ja tormid tulevad ja tema oodatud ja loodetud ja Looja poolt õnnistuseks jagatud kätetöö, tema töö ja vaeva ja palehigi ära puistavad. [---] Otse sarnane lugu on juba mõni aeg meie rahva vanavaraga, kellel juba ammugi viimne lõikuse silmapilk kätte on jõudnud ja terad juba mõni aeg maamulda maha on hakkanud varisema, ei mitte, et seal uusi idusi ajada ja uueks viljaks võsuda, vaid igaveseks ajaks ja jäädavalt põrmuks kõduneda ja peastmata kaduma minna (Reinvald 1893a).

Asetades rõhu kogumistöö kiireloomulisusele, seab Reinvald kahtluse alla mitmete töödega hõivatud Hurda võime üksinda kogu valdkonda piisavalt efektiivselt hallata. Nii esitab ta Eisenit kui väga oodatud abiväge ja küsib: „Kuidas Hr Hurt seda lahutuseks võib ütelda, kui kaks töötajat ühel ja sellel samal põllul töötavad, on arusaamata” (Reinvald 1893a). 
Grenzstein toetub sarnaselt Hurdaga põllu-metafoorika piiritlevale poolele ning nõuab, et Eisen leiaks endale mingi muu (teiste poolt hõlvamata) valdkonna. Sealjuures lubab ta lugejatele, et võtab Eiseniga isiklikult ühendust, et uues valdkonnas kokku leppida, ning pakub Eisenile igakülgset abi uue põllu arendamiseks: ${ }^{10}$

Suguvend õp. Eisen, peaks enesele mõne teise tööpõllu võtma, ükskõik missuguse. Neid on meil palju. On ta sellel põllul oma tööd alustanud, siis maksab seesama eeskiri ka tema kohta. Tema on töö juhataja sellel põllul ja kõikide kohus on, teda aidata ja tema soovisid täita. Et Olevik praegu tema vanavara korjamise vastu kirjutab, siis tahab ta temale seda suurema südidusega abiks astuda ja ta tööd jõudu mööda edendada, niipea kui suguvend adra pihku võtnud (Grenzstein 1894e).

Siiski pole Grenzsteini eesmärgiks üksnes Hurda valdkonna iseolemise kaitsmine, vaid soov kultuurivaldkonnas tervikuna korda majja lüüa. Näiteks avaldab Grenzstein lootust, et Hurt võtab üle ka need rahvaluuleteemad, mille kogumine lähtus Eiseni algatusest (nt nimede korjamise, vt Grenzstein 1894a), samuti rõhutab ta, et kultuurivaldkonna kui terviku seisukohalt on vanavara uurimine ja kogumine vaid üks (ja üldsegi mitte kõige prioriteetsem) detail: „Aga nagu meie juba enne siin kohal oleme kord seletanud, ei ole räägitav vanavara mitte ainus asi, mis meil armas, kallis ja kasulik on. Meil on neid asju enam. Kõik, mis meie kodumaasse ja tema pärisrahvasse puutub, tuleks hoolsa, plaanilise töö alla võtta" (Grenzstein 1894e). Selline plaanide visandamine, nähtuste asetamine üldisemasse konteksti on Grenzsteini kirjatükkides üsna tavaline (vt nt Peegel 1994: 183-184).

\section{Rahvaluule väljaandmine}

Lisaks küsimusele, kellel on õigus rahvaluulet koguda, puudutab diskussioon ka kogutu edasist saatust. Viitasin eelnevalt juba Reinvaldi ja Grenzsteini ideedele originaaltekstide hoiustusvõimalustest (palju erakogusid, mille võib kunagi tulevikus ühendada $v s$. ühtse süsteemiga tsentraalarhiiv), kuid tunduvalt kesksemaks kujunes küsimus raamatute väljaandmisest ehk siis sellest, millisel kujul (ja millal!) peaksid materjalid tagasi rahva sekka jõudma.

1893. aasta mais märkis Vilde, et see, milliseid väljaandeid Eisen koostab, annab tema muidu dubleerivana näivale tegevusele õigustuse: eesti rahvas vajab nii teaduslikke käsitlusi kui ka rahvale mõeldud meelelahutuslikke väljaandeid (Vilde 1893b). Samas on Hurt seisukohal, et vaja on üksnes teaduslikke väljaandeid, Eiseni raamatuid nimetab ta vanavara varajaseks äratrükkimiseks ja kirvetööks.

Teadusliku väljaande esmaseks tunnuseks on lähtumine võimalikult terviklikust korpusest: „Niisugused raamatu vihukesed [s.o Eiseni väljaanded

${ }^{10}$ 1895. aasta jaanuaris Olevikus avaldatud lugejakirjas soovitavad kooliõpetaja P. Fr. Kõiv ja köster Joh. Raudsepp Eisenile ka konkreetset projekti: ristimise- ja hauakõnede raamatu koostamist. Oma kirjutises kasutavad nad samuti põllu metafoori piiritlevat tähendust: loodame, et Eisen peab võimalikuks „uuel aastal oma tööpõldu muuta ja tähendatud raamatu kallale tööle hakata" (Grenzstein 1895). 
- K. K.] ei tähenda meie vanavara korjamise tööl mitte midagi, rahvas tunneb seda materjali isegi, teadus ei saa väikesi vihukesi silmagi. Üksnes üks suurem kogu, nagu meie ühine töö on, mõjub siin ja maksab siin” (Hurt 1891). Seega igasugune publikatsioon, mis on välja antud, enne kui kõik rahvaluule on kokku kogutud, on varajane, ning võib mõjutada õigeaegse sisu - võib ju juhtuda, et kogujad ei pea vajalikuks märkida üles palasid, mida nad on kusagilt lugenud. ${ }^{11}$

Väljaandmisprotsessi kirjeldades kasutab Hurt ehitustegevusega seotud metafoore: väljaanne on ehitis, mida on võimalik edukalt püstitada vaid siis, kui kogu materjal on ühes kohas koos, ning see materjalikogum peaks olema nii esinduslik, et ta lihtsalt kutsub endast ehitust tegema: „Mida nägusamalt ja rohkemalt tema üheskoos on, seda enam on julget ja rõõmsat lootust, et ühel ehk teisel viisil nõuu leitakse, nii tähtsat ja kaunist materjaali ilmutada. Mõjuvad silmad ja tugevad käed ei või temast mööda minna, nad peavad temast kinni hakkama ja temast ehituse tegema" (Hurt 1893a). Rõhutades aga, et ehitus võib olla teostatud kas oskaja meistri poolt sirkli ja höövliga või jääda kirvetööks, kasutab Hurt seda metafoori lisaks kunagi tulevikus teoks saavate väljaannete suurejoonelisuse rõhutamisele ka Eiseni ebapädevuse rõhutamiseks: „Eisen paneb vanavara, mis ta saab ruttu ja pea trükki. Kriitika, uurimine, sõelumine on sedaviisi temal võimata. [---] Ütleme piltlikult: Töö jääb kirvetööks, sirkel, höövel, viil puuduvad” (Hurt 1893a).

Virmaline ja Valgus rõhuvad rahvaluulele kui rahva ühisomandile (Valgus nimetab kogutavaid materjale peaaegu läbivalt rahvalikeks vanadeks varandusteks). Esiplaanil on rahva õigus kogutud materjalidest osa saada ning nende uurimisel ja tõlgendamisel osaleda:

Ei! kellegi rahva vanavarandus pole sarnane asi, mida üks inimene ainult enese vaimu mõedupulgaga suudaks ehk jõuaks ära mõeta ja selle üle otsust teha. Mida enam kogujaid ja sõelujaid, seda tähtsam võib saada - vaim u - vili (Kõrv 1893).

Valguse ja Virmalise keelekasutuses on rahvaluule väljaandmine selle valguse kätte toomine - kujund, mis esitab väljaandmist kui iseenesestmõistetavat jätku kogumisele, mida samuti sageli sama metafoori abil kirjeldatakse. Nii kirjutab Virmaline: „Et hra Eisen oma vanavara kohe trükki paneb, pole sugugi nii kurtmise väärt ülekohus, sest mis trükis on, see on meil käes - see on peastetud [---] See on avalik ja päevavalgel tehtud töö, mille vili aeg ajalt igale silma paistab" (Reinvald 1893b). Ja Valgus:

Meie ei mõista arusaada, kuidas need Eesti vanavara osad, mis Eisen kogub ja trüki läbi avaldab, kadumist piaksivad tähendama, kuna mõne muu mehe surnult tolmu sees seisev vanavara-kogu otse nagu raudvaraks näikse arvatavat! Meie teades saavad rahvalikud vanad varandused seda enam avaldusele äratatud, kui rahvas neid mõnelgi näul juba trükis lueb! (Kõrv 1893.)

${ }^{11}$ „Varajane äratrükkimine on ka sellepoolest kahjuline, et materjaali teisendid selleläbi vähendatud saavad ehk ka üsna tulemata jäävad. Lugeja leiab raamatust jutu ehk vana usku, vana kombe tüki. Tema tunneb ka mõne sarnase. Ta ei arva enam tarviliseks oma teadmisi paberisse panna ja vanavara aita saata, see olevat asjata. Raamatus on ju sarnane tükk üleval. Mis pisukene vahe välja teeb? Ja ometi on niisugused pisukesed vahed teaduste uurimisel tihti ülitähtsad ja teisendid sellepärast väga tarvilised" (Hurt 1893a). 
Erinevalt Hurdast, kes muretseb, et varajane väljaanne pärsib teisendite laekumist, leiab Virmaline, et väljaanded ergutavad kogumistööd:

Peale selle ergutab ta korjajaid uuele hoolsale korjamisele, kui nad oma korjanduse töö vilja ju osastiki näha saavad, pealegi veel iseenesele mälestuseks, kui kõige auusamal kombel teenitud töö palk kingituseks kätte saab saadetud (Reinvald 1893b).

Ka Postimees ja Olevik väljendavad veendumust, et rahvaluulel põhinevad väljaanded on iseenesest hea ja kasulik lugemisvara. Kuid rahvaluule kui ühise varanduse asemel viitavad nad väljaandja kohustusele tagada, et rahvale lugemiseks mõeldud raamatud ei läheks vastuollu moraalsete tõekspidamistega. Nii kirjutab Postimees, et Eiseni rahvaraamatud ei sisalda kunagi puhast folkloori, vaid alati rahvalikku lugejat silmas pidades silutud-kohendatud lugusid:

Kuid seesugune silumine ei tõsta mitte vanakulla hiilgust, vaid endine helk läheb kaotsi. Ilma silumata ei saaks aga herra Eisen seda tarbetagavara mitte kokku liita rahvale raamatuteks, sest see oleks sagedasti meie rahva kõlbelise arvamisele väga suureks kahjuks ja kahjutegijaks. Meie ei tohi oma esivanemate pärandust mitte valesti tarvitama hakata (Eesti vanavara 1893).

Ja Olevik muretseb, et kiiruga koostatud väljaanded võivad tekitada haritud inimestes vastuseisu kogumistööle kui sellisele:

Rutulisel trükkimisel on veel teine viperus. Meie vanavara raamatutes oleks palju kraami, mis kõlbuliste küsimuste pärast sugugi rahva sekka ei sünni välja läkitada. Et see aga oleks sündinud, siis saaks meie rahva seas küllalt neid olema, kes sellep. üleüldse meie vanavara kirjakogu va st u oleksivad, ja seda peaksivad nad olema (Grenzstein 1894d).

Postimees nõustub Hurda seisukohaga, et väljaannete koostamine peab jääma teadlastele. Nõustumist rõhutab ka tema kasutatud ehitusmetafoorika edasiarendamine. Nii võrreldakse Hurda töö tulemust lossi ning Eiseni oma onniga, „mille ehitaja oleks ehk sunnitud tarbepuude puudusel suure maja seinadest palkisid väljamurdma" (Eesti vanavara 1893). ${ }^{12}$ Ning teadusväljaannete loomist iseloomustatakse kui suure teaduse koja ehitamist:

...palju on sääl, mis ainult teadusele toredaks tarbepuuks on, millest ülesehitab teadus meie vanemate vaimu- ja tegelisest elust suure koja, kust meil vastupaistab meie vanemate kuju täies selguses ja selles peeglis end vaadeldes hakkame iseennast rohkem mõistma oma olevikust arusaama ja tulevikku võime säält ettenäha. Kuid selleks ei ole meie vanakuld mitte, et meie tema ilma seletusetuleta jälle soojaks teeksime ja sellega ennast sedaviisi toita katsuk-

${ }^{12}$ Seda arendust kommenteerib omakorda Virmaline: „Meie ei usu mitte, et üks „vilets onnike”, nagu Postimees omas liias vaimustuse tuhinas Eiseni tähtsat isamaalist tööd nimetab kedagi ostuhimulist „toredat hoonet” keelaks ostmast, kui aga ostjal sedavõrd raha kukrus olemas on. Oskab ja jõuab aga ehitaja meister arvatud „viletsa onnikese” asemel niisama toreda ehk veel toredama maja oma terava kirve, höövli, viili ja loojast jagatud varandusega ülesse ehitada, kui tema ehitaja naaber, siis ei ole sinna midagi parata" (Reinvald 1893b). 
sime. Ja ometi oleks „Rahva raamatute” kujul ilmutatud vanavaral sarnane siht! (Eesti vanavara 1893.)

Nagu juba viidatud, on Grenzstein seisukohal, et trükkimine „on meie järeltulijate asi” (Grenzstein 1894d). Siiski pakub ta välja ka seda, millised need (tulevikus koostatavad) väljaanded olla võiksid. Nii mainib ta teadlaste koostatud väljaandeid, kuid leiab, et need peaksid olema suunatud teadlastele, ning nende loomisega pole mõtet kiirustada. Tunduvalt olulisemaks peab ta rahvaväljaandeid, mille loovad korrastatud rahvaluulekogudele tuginedes kirjanikud:

Niisugune vanavara tarvitamine on see, mida rahvale tuleb soovida. Ta nõuab kirjanikult töö d, aga ehk tulevad ka ajad, mil tööd mõistetakse auustada. Tahavad Eesti pojad tõsist eestilist tööd oma kirjanduse põllul luua, siis uurigu nad oma esivanemate vaimutöö läbi ja kasvagu ja kangenegu nende najal. See vaimutoit on Soomesugu rahvaste põllul kasvanud ja peab sellele iseloomule iseäranis kosutav olema (Grenzstein 1894e).

Viimasest tuleb esile Grenzsteini praktiline meel: ehkki teadus on oluline, ei tohi vanavara valdkond jääda kabinetiteaduseks, vaid peab olema abiks ja eeskujuks teistele (mitte nii hästi korraldatud) kultuurivaldkondadele. ${ }^{13}$

\section{Kokkuvõte}

Käesoleva artikli eesmärgiks on pöörata enam tähelepanu sellele tähendusraamile, mille andis rahvaluule kogumisele ajakirjandus. Siinses artiklis käsitlesin seda problemaatikat seoses ühe konkreetse - Hurda ja Eiseni paralleelsele kogumistööle keskendunud - diskussiooniga. Ent arvestades seda, kui oluline oli ajalehtede roll rahvaluule kogumise aktsioonide õnnestumises, vajaks see käsitlus tulevikus kindlasti avardamist. Näiteks võiks kaardistada selle osa ajakirjandusmaastikust, mis üldse rahvaluule kogumisele tähelepanu pööras (see osa oli tunduvalt suurem kui siin artiklis käsitletud neli väljaannet), ent siinse artikli teemast lähtuvalt vääriks tähelepanu ka Hurda ja Eiseni meediakasutuse erinevus.

Üheks mu lähtepunktiks oli idee, et tolleaegne ajakirjandusväli ise oli mitmetine ja vastuolusid täis, ning samavõrra kui rahvaluule kogumise organiseerijad kasutasid ajakirjandust omadel eesmärkidel, oli ajakirjanikel võimalik kaasata rahvaluuleteemasid neid huvitavate teemade arutellu või omavaheliste jagelemiste raamistusse. Grenzstein leiab talle omaselt võimaluse kohe suuri plaane visandama hakata, pakkudes välja võimalusi nii valdkonna sise-

${ }^{13}$ Ideed, et rahvaluulekogumine võiks olla kirjandusvaldkonna arendamise eeskujuks, on Grenzstein väljendanud ka varem. Näites 1889. aastal tegi ta ettepaneku kutsuda ellu midagi rahvaluulekogumisega võrreldavat kirjanikele: „Mis haridus ja osav juhatus siin suudab korda saata, eks me seda näe vanavara korjamise juurest. Oleks meil uuevara kasvatamise juures ka sedamoodu tööplaan olevat, see saaks oma jagu vilja kandma. Rahva kirjavara kui üks jagu rahva vaimutoitu on küll seda väärt, et tema eest väsimata hoolt kantakse. [---] Mis oleks, noored kirjamehed ja suguvennad, kui meie mõne Oleviku veeru kirjanikkude kogumise kohaks teeksime? Kas ei oleks kasulik, kui meie siin hästi korda läinud kirjatöö proovisid avaldaksime ja nende arvustusele ka maad annaksime?" (Grenzstein 1889). 
miseks arendamiseks kui ka selle suhestamiseks avarama kultuuriruumiga. Virmaline ja Valgus aga asuvad kaitsma ajakirjandusvälja mitmetisust. Virmalise süüdistus - nii kaua kui Hurt saadab oma aruandeid vaid kahte ajalehte, ei saa tema nõuet, et rahvaluulet tohib saata vaid talle, pidada erapoolikuks - võib tänapäeval näida ülepakutuna, kuid see näib viitavat Reinvaldi usule, et rahvaluulekogujad on lugejarühm, kelle hoidmisse tasub panustada. Ka on konkurentide süüdistamine ühe või teise teema monopoliseerimises või lugejate ülelöömise katsetes üsnagi tavaline osa ajakirjandusväljasisesest suhtlusest.

Hurda 74. ja 88. kogumisaruanne olid näited sellest, mida ma eelnevas Briggsile (2008) toetudes nimetasin piiritlemiseks: tema eesmärgiks oli luua selge erinevus enda ja Eiseni tegevuse vahele. Üheks vahendiks, mille abil ta selle piiri tõmbas, olid metafoorid: rahvaluule valdkonna kujutamine iseseisva põlluna võimaldas tal näidata Eisenit võõrale territooriumile tungijana ning rahvaluuleväljaannete võrdlemine ehitistega viidata Eisenile kui amatöörile.

Järgnenud arutelu võib ühelt poolt vaadata kui Eiseni ja Hurda pooldajate vastasseisu, kuid nagu nägime, olid Hurta toetanud Postimehe ja Oleviku seisukohad pigem ambivalentsed, kuivõrd mõlemad on varem toetanud ka Eiseni ettevõtmisi. Postimehe osas jääb lahtiseks isegi see, mis seisukohale oleks väljaanne asunud (või kas ta oleks üldse sekkunud), kui Hermann ise oleks Eestis olnud. Eisenit toetanud Virmaline ja Valgus määratlesid endid aga Jakobsoni pooldajatena - seega võib nende sõnavõtte käsitleda ka kui võimalust väljendada oma suhtumist Hurda tegevusse (ning Eiseni kaitstava-staatus on pigem juhuslik). Ka ei tähenda Hurda pooldamine tema nägemuse igakülgset toetamist: Grenzstein annab küll õiguse Hurdale, kuid taandab tema valdkonna üheks väga paljude teiste seas, samal ajal kui Hurta vastustav Reinvald rõhutab rahvaluulekogumise kesksust.

Peaaegu kõik diskussiooni osalised näivad toetavat Hurda lähtepunktiks võetud ideed kultuurist, mis jaguneb teineteisest selgelt eristuvateks põldudeks, millest igaühel võiks olla üks ülevaataja - küsimuse all pole mitte piiride olemasolu, vaid nende paiknemine. Väga tüüpiliseks põhjenduseks range tööjaotuse vajalikkusele on inimressursside vähesus - vanasõna meil on palju tööd, aga vähe töölisi esineb natuke erinevates sõnastustes kolme osalise tekstis (Hurt 1893a; Grenzstein 1894e; Reinvald 1893a). On kõnekas, et seda vaadet jagab ka Eisen - diskussiooni raames ta küll avalikult sõna ei võta, kuid kirjutab sellest Hurdale (KM EKLA, f 43, m 2 : 49, 1 4/9-4/10) ja Grenzsteinile (KM EKLA, f 38, m 1, l 34-35). ${ }^{14}$ Eiseni nägemuses eristab tema ja Hurda valdkonda erinev žanriline koostis, mida ta täpsustab küll mõlemal juhul negatiivselt viitena žanridele, millega tal pole plaanis tegelema asuda: „Minul ei ole iial mõttesse tulnud vanu sõnu, laulusid jne välja anda” (KM EKLA, f 38, $\mathrm{m} 1,134)$.

Sama levinud kui usk valdkondade jagamise vajalikkusse on aga ka vaidlemine ühe või teise isiku haldusala piiride paiknemise üle. Ühe näitena vii-

${ }^{14}$ Kiri on dateerimata, Ülo Tedre pakub, et see pärineb 1893. või 1892. aastast ning et tegu on vastusega mõnele Grenzsteini kaotsi läinud kirjale (vt Tedre 1994: 495). Samas viitavad mitmed märgid seosele Grenzsteini 1894. aasta detsembri kirjutisega (Grenzstein 1894c; 1894d; 1894e): kirjas on teemasid, mida aasta või kaks varem avalikus kirjasõnas ei arutatud, kuid Eisen viitab, et tekst on vastuseks just ajalehes ilmunule: „Sinu arutamise peale lehes..." (KM EKLA, f 38, m 1, 1 35). Sellele, et 1894. aasta lõpus Eiseni ja Grenzsteini vahel mingi suhtlus toimus, viitab ka 1895. aasta jaanuari Olevikus olev Grenzsteini märkus, et kirjavahetus Eiseniga ei viinud sihile (Grenzstein 1895). 
tasin eelnevalt Jungi rünnanud Grenzsteinile. Kuid oli põnev avastada ka pea kümme aastat hilisemast ajast pärinev kiri, kus Hermann süüdistab Hurta enda pädevusvaldkonda tungimises (ning vanavara valdkonna hooletusse jätmises):

Mina olen terve eluaja kirjamees olnud ja poole inimesepõlve oma emakeelt ülikoolis ette kandnud, olen siis vist küll eesti keele uurimise töö kesktipul seisnud. Sinu aja on õpetaja-ameti töö ära kulutanud, selle pärast ei või Sa enam mitte keele-õpu kõrgemaks jääda, jää siis sellest eemale ning hakka vanavara tööle, kus Sa tõesti asjatundja oled. Ise oled ütelnud, et peame tööd jagama, ära siis kipu minu alale, tee vanavara tööd, muidu ei pea Sa oma sõna (KM EKLA, f 45, m $7: 23,1$ 2/3). ${ }^{15}$

Ka küsimus rahvaluule väljaandmisest asetub ajakirjanduses mõnevõrra avaramale taustale: samuti kui rahvaluule kogumist käsitleti lisaks teaduslikule ka üldrahvaliku ettevõtmisena, mõtestati rahvaluuleväljaandeid üldisema kirjanduskonteksti osana. Tolleaegne ajakirjandus väljendas sageli muret kaasaegse lugemiskultuuri kehva taseme pärast: häid raamatuid ilmub väga vähe ning need, mis ilmuvad, ei jõua lugejateni. Ajakirjandus esitas neis diskussioonides ennast kui autoriteeti, kelle hinnangutele tuginedes peaksid inimesed valima lugemisvara, ning samuti kui kanalit, mille kaudu kirjutajad peaksid oma raamatuid reklaamima. Rahvaluulega seotud väljaanded (sealjuures ka Eiseni omad) leiavad neis aruteludes alati väga positiivset esiletõstmist. Diskussiooni raames Postimehe ja Oleviku tõstatatud küsimus rahvaluulematerjali potentsiaalsest ebamoraalsusest esineb ajakirjanduses küll mõnevõrra seoses rahvaluule kogumisega (nt Hurt 1888), kuid raamatute ülevaadetest me midagi sellist ei leia - pigem väljendavad arvustajad alati rõõmu selle üle, et kogutu rahva hulka tagasi jõuab (ehk siis seisukohta, mida diskussioonis esindasid Virmaline ja Valgus).

Suhtumist Eiseni väljaannetesse mõjutas kindlasti ka see, et lugemisteemalistesse debattidesse panustas ka Eisen ise ning tema vaade raamatutele oli vägagi praktiline. Erinevalt Hurdast, kes (vähemalt antud diskussiooni raames) pidas oluliseks, et raamat annaks mingist kultuuri aspektist võimalikult täieliku pildi, oli Eiseni jaoks raamat vahend inimeste (rahva) üldise mõtte- ja elulaadi suunamiseks. Viimast väljendasid näiteks tema 1890. aastate alguses Postimehes avaldatud karskusteemalised juhtkirjad, kus ta soovitas asendada viin raamatutega (vt nt Eisen 1891; 1892).

Selle eristusega haakub kenasti Kristin Kuutma tähelepanek, et Eiseni ja Hurda tegemisi kõrvu seades tuleks meeles pidada, et nad kuulusid erinevatesse põlvkondadesse ja intellektuaalsetesse keskkondadesse: „Hurt töötas saksastunud vaimses kontekstis ja tal oli väga vähe lootust eesti identiteedi elujõulisusele, samas kui Eisen kõnetas auditooriumi, kes mitte üksnes ei mõelnud, vaid ka luges ja kirjutas eesti keeles" (Kuutma 2005: 93). Mõnevõrra üldistades võib väita, et kui Hurt näeb rahvaluuleväljaandeid rahvuskogukonna kui terviku sümboolse väljendusena, siis Eisen leiab, et nad peaksid panema aluse kogukonnale, mis koosneb lugevatest (tähenduses: haridusele püüdlevatest) indiviididest.

${ }^{15}$ Hurda vastus: KM EKLA, f 45, $\mathrm{m} 1: 2,1$ 1/1. 
Siinjuures pole küsimus selles, kumb neist on õige või vale, vaid kontekstides, kuhu üks või teine nägemus paremini sobib. Hurda rõhk teaduslikkusele (ning rahvusvahelise teadusmaailma heakskiidule) oli vältimatu, selleks et rahvaluulekogumist üldse omas ajastus aktsepteeritavaks muuta (nii välistati süüdistused ebausu levitamises). Samas ühtis Eiseni rakenduslik lähenemine tunduvalt paremini kaasaegse ajakirjanduse (ehk siis rahvaluule sõnumite edastamiseks kasutatava meediumi) üldisemate rõhuasetustega. Teadus oli selles kontekstis küll üsna kõrgelt hinnatud märksõna, kuid selle rakendus ei pruukinud olla nii rangelt piiritlev ja kõigi teiste suhtes kõrgemal positsioonil, vaid pigem otsiti erinevate valdkondade ja lähenemisviiside vahelisi kokkupuutepunkte ning vaidlusvõimalusi.

Artikkel on seotud teadusteemaga „Folkloori narratiivsed aspektid. Võim, isiksus ja globaliseerumine" (SF0030181s08).

\section{Kirjandus}

Ajalehtede keskel 1894. - Sakala 9. III.

Ander s o n, Benedict 2006. Imagined Communities. Reflections on the Origin and Spread of Nationalism. London-New York: Verso.

A r u, Krista 1994. „Postimees”. - Eesti ajakirjanduse teed ja ristteed. Eesti ajakirjanduse arengust (XVII sajandist XX sajandini). Koost Juhan Peegel. TartuTallinn: Tartu Ülikooli ajakirjandusosakond, lk 206-214.

B r ig g s, Charles 2008. Disciplining Folkloristics. - Journal of Folklore Research. Grand Theory, kd 45, nr 1, lk 91-105.

Eesti vanavara 1893 = Eesti vanavara korjamisest ja keelemurrete uurimisest. Postimees 17. VIII.

E i s e n, Matthias Johann 1891. Alkohol ja kirjandus. - Postimees 22. VIII.

E i s e n, Matthias Johann 1892. Sõitjatele tähelepanemiseks. - Postimees 17. VII.

E i s e n, Matthias Johann 1893. Rahvaluule ja selle avaldamine. - Eesti Postimees 15. XI.

[G r e n z s t e i n, Ado ] 1889. Noortele kirjameestele. - Olevik 22. XII.

[G r e n z s t e in, Ado] 1894a. Eesti vanavara. - Olevik 28. II.

[G r e n z s t e i n, Ado] 1894b = Kirjandus. Seltsielu. Segasõnumid. - Olevik 20. XII.

[G r e n z s t e in, Ado] 1894c. Vanavara asjus I. - Olevik 6. XII.

[Gr e n z s t e i n, Ado] 1894d. Vanavara asjus II. - Olevik 13. XII.

[G r e n z s t e i n, Ado] 1894e. Vanavara asjus III. - Olevik 20. XII.

[Gr e n z s t e i n, Ado] 1895. Vanavara asjus. - Olevik 17. I.

[H e r m a n n, Karl August] 1895. Kirjandusest. - Postimees 15. III.

H u r t, Jakob 1888. Kümnes aruanne Eesti vanavara korjamisest ja keelemurrete uurimisest. 8. Septembril 1888. - Postimees 10. IX; Olevik 12. IX.

H u r t, Jakob 1889. Viieskümnes aruanne Eesti vanavara korjamisest ja keelemurrete uurimisest. 2. Novembril 1889. - Postimees 7. XI; Olevik 6. XI.

H u rt, Jakob 1891. Seitsmeskümnes neljas aruanne Eesti vanavara korjamisest ja keele murrete uurimisest. 24. Oktobril 1891. - Postimees 4. XI; Olevik 4. XI.

H u r t, Jakob 1893a. Kaheksaskümnes kaheksas aruanne Eesti vanavara korjamisest ja keelemurrete uurimisest. 11. Augustil 1893. - Postimees 16. VIII; Olevik 16. VIII. 
H u r t, Jakob 1893b. Üheksakümnes kolmas aruanne Eesti vanavara korjamisest ja keelemurrete uurimisest. 8. detsembril 1893. - Postimees 17. XII, 22. XII; Olevik 13. XII.

J a n s e n, Ea 2004a. Jakob Hurt ja ühine isamaa töö. - Ea Jansen, Vaateid eesti rahvusluse sünniaegadesse. Tartu: Ilmamaa, lk 19-35.

J a n s e n, Ea 2004b. Veel kord ärkamisaja kultuurimurrangust. - Ea Jansen, Vaateid eesti rahvusluse sünniaegadesse. Tartu: Ilmamaa, lk 60-102.

J a n s e n, Ea 2004c. Eesti ajakirjanduse rahvuslikkusest venestamisajal. - Ea Jansen, Vaateid eesti rahvusluse sünniaegadesse. Tartu: Ilmamaa, lk 181-204.

J a n s e n, Ea 2004d. Ühest dialoogist surveaegade ajakirjanduses. - Ea Jansen, Vaateid eesti rahvusluse sünniaegadesse. Tartu: Ilmamaa, lk 319-337.

$\mathrm{K}$ a $1 \mathrm{k} \mathrm{u} \mathrm{n}$, Andreas 2011. Kellele kuulub seto pärimus? Samuel Sommeri rahvaluulekogu loost ja retseptsioonist. - Seto laul eesti folkloristika ajaloos. Lisandusi representatsiooniloole. Tartu: Tartu Ülikooli Kirjastus, lk 189-236.

Kirjandus 1892 = Kirjandus. Seltsielu Segasõnumid. - Olevik 28. XII.

Kirjandus 1893a = Kirjandus. Seltsielu. Segasõnumid. - Olevik 31. V.

Kirjandus $1893 \mathrm{~b}=$ Kirjandus. Seltsielu. Segasõnumid. - Olevik 30. VIII.

Kirjandusest 1893. - Postimees 20. IV.

[K õ r v, Jakob] 1893. Kirjandusest. - Valgus 24. VIII.

K u u t m a, Kristin 2005. Matthias Johann Eisen: A Collector and Publisher of Narratives. - Studies in Estonian Folkloristics and Ethnology. A Reader and Reflexive History. Tartu: Tartu University Press, lk 79-99.

L a u g a s t e, Eduard 1963. Eesti rahvaluuleteaduse ajalugu. Valitud tekste ja pilte. Tallinn: Eesti Riiklik Kirjastus.

L a u k, Epp 1994a. „Valgus”. - Eesti ajakirjanduse teed ja ristteed. Eesti ajakirjanduse arengust (XVII sajandist XX sajandini). Koost Juhan Peegel. TartuTallinn: Tartu Ülikooli ajakirjandusosakond, lk 196-201.

L a u k, Epp 1994b. „Virmaline”. - Eesti ajakirjanduse teed ja ristteed. Eesti ajakirjanduse arengust (XVII sajandist XX sajandini). Koost Juhan Peegel. TartuTallinn: Tartu Ülikooli ajakirjandusosakond, lk 202-205.

Mis teevad teised lehed? 1888 - Olevik 30. V.

P e e g e 1, Juhan 1994. „Olevik”. - Eesti ajakirjanduse teed ja ristteed. Eesti ajakirjanduse arengust (XVII sajandist XX sajandini). Koost Juhan Peegel. TartuTallinn: Tartu Ülikooli ajakirjandusosakond, lk 177-195.

P õ l d m ä e, Rudolf 1989. Materjale J. Hurda vanavara kogumise loost. - Paar sammukest eesti kirjanduse uurimise teed XII. Uurimusi Jakob Hurda 150. sünniaastapäevaks. Tallinn: Eesti Raamat, lk 10-40.

Rahvaluule 1894 = Rahvaluule ehk vanavara korjamine 1894. Kasuline Talurahva Kalender 1895. Jurjev: Schankenburgi trükk ja kulu, lk 43-44.

[R e i n v a l d, Jaan] 1893a. Meie vanavara korjamisest. - Virmaline 26. VIII.

[R e i n v a l d, Jaan] 1893b. Meie vanavara korjamisest II. - Virmaline 3. IX.

T e d r e, Ülo 1994. M. J. Eiseni tee folkloristikasse (II). Eisen Hurda võistlejana. Keel ja Kirjandus, nr 8, lk 487-497.

Teistest ajalehtedest 1888. - Virulane 23. V.

Toimetuse poolt 1893. - Olevik 16. VIII.

Toimetuse tähendus 1893. - Virmaline 9. IX.

Tõistest ajalehtedest 1892. - Sakala 22. IV.

V a l k, Ülo 2004. On the discursive foundations of Estonian folkloristics: a farmer's field of vision. - Ene Kõresaar, Art Leete (toim), Everyday Life and Cultural 
Patterns: International Festschrift for Elle Vunder. (Studies in Folk Culture 3.) Tartu: Tartu University Press, lk 265-272.

V a lk, Ülo 2008. Saksad ja varavedajad: eesti muistendite sotsiaalsest orientatsioonist. - Kes kõlbab, seda kõneldakse. Pühendusteos Mall Hiiemäele. Koost Eda Kalmre, Ergo-Hart Västrik. Tartu: Eesti Kirjandusmuuseumi Teaduskirjastus, lk 57-73.

Vanavara korjajalt 1892 = Vanavara korjajalt vanavara korjajatele. - Olevik 2. IV.

V i i d a l e p p, Richard 1980. Jakob Hurda üleskutse „Paar palvid”. - Keel ja Kirjandus, nr 5, lk 282-290.

[Vil d e, Eduard] = -e. 1893a. Kirjandusest. - Postimees 28. V.

[Vil d e, Eduard] = -e. 1893b. Kirjandusest. - Postimees 19. VIII.

\section{The press and Jakob Hurt's and Matthias Johann Eisen's efforts of col- lecting folklore}

Keywords: folklore collecting, 19th century press, folklore publishing, Jakob Hurt, Matthias Johann Eisen

The article is focused on the press debate of 1893-1895, triggered by Jakob Hurt's criticism of Matthias Johann Eisen's methods of folklore collecting. Besides the invaluable role played by the press in the success of the collecting campaigns, one should also consider the multi-pronged nature of the local press sphere of the late 19th century. While the collectors used the press for their own purposes, the journalists felt free to make use of folklore topics in various other discussions and mutual disputes. Analysing the positions of four newspapers - Postimees, Olevik, Virmaline and Valgus - the article attempts to capture the general significance of the campaigns for the cultural space of the time. Hurt's argumentation was based on his view of the scientific approach as the only right way, whereas the journalists put forward another perspective.

Katre Kikas (b. 1981), researcher, Estonian Literary Museum, Department of Folklore; doctoral student, University of Tartu, katreki@folklore.ee 